Chirurgia (2021) 116: 224-231

No. 2,

Copyright@ Celsius

http://dx.doi.org/10.21614/chirurgia.116.2.224

\title{
The Impact of Post-Mastectomy Radiotherapy on Delayed Alloplastic Breast Reconstruction - Experience of One Center
}

\author{
Andrei Ludovic Porosnicu ${ }^{1,2}$, Ioana Ghiurco $0^{1,2^{*}}$, Vlad Petre Atanasescu ${ }^{2}$, Ștefania-Mihaela Riza ${ }^{2}$, \\ Cristian Sorin Hariga ${ }^{1,3}$, Ioan Lascăr ${ }^{1,3}$, Ruxandra Diana Sinescu ${ }^{1,2}$ \\ ${ }_{1}^{1}$ "Carol Davila” University of Medicine and Pharmacy, Bucharest, Romania \\ ${ }^{2}$ Department of Plastic Surgery and Reconstructive Microsurgery, „Elias” Emergency University Hospital, Bucharest, Romania \\ ${ }^{3}$ Department of Plastic Surgery and Reconstructive Microsurgery, Clinical Emergency Hospital, Bucharest, Romania
}

${ }^{*}$ Corresponding author: Ioana Ghiurco, MD

Department of Plastic Surgery and Reconstructive Microsurgery

"Elias” Emergency University Hospital Bucharest, Romania

E-mail: ioanaghiurco@yahoo.com

\section{Rezumat}

Impactul radioterapiei post-mastectomie asupra reconstructiei mamare întârziate cu materiale aloplastice - experiența unui centru

Context şi obiective: În prezent, tratamentul cancerului de sân implică o gama largă de proceduri de la simpla excizie a leziunilor până la managementul complex, ce presupune intervenție chirurgicală (mastectomie cu sau fără limfadenectomie axilară) şi tratament adjuvant (chimioterapie, radioterapie, terapie hormonală sau imunoterapie). Reconstrucția postmastectomie poate fi privită ca o parte a abordării cancerului mamar, dar, deşi beneficiile sale fizice şi emoționale sunt incontestabile, vine cu propriul set de riscuri şi complicații, mai ales atunci când se efectuează la distanță la paciente cu radioterapie. Această lucrare îşi propune să prezinte experiența noastră in ceea ce priveste efectele radioterapiei asupra reconstructiei mamare întârziate cu materiale aloplastice.

Materiale si metode: Am realizat un studiu retrospectiv pe 16 pacienți cu mastectomie pentru cancer mamar, pentru care $\mathrm{s}^{-\mathrm{a}}$ realizat reconstrucție la distanță. In funcție de efectuarea radioterapiei postmastectomie, pacienții au fost repartizați în unul din cele două grupuri: grupul 1 a fost format din opt paciente care au primit radioterapie adjuvantă şi grupul 2 din opt paciente fără radioterapie. Am colectat o serie de date (sociodemografice, tipul intervenției reconstructive, terapii adjuvante etc.) şi ulterior am analizat cazurile în care au apărut complicatiii.

Rezultate: Numărul şi severitatea complicațiilor după reconstrucția mamară a fost mai mare în grupul pacientelor cu radioterapie adjuvantă. Şapte paciente au prezentat complicații, dintre 
care trei au fost majore: necroză parțială a lamboului TRAM, extruzie de expander şi celulită a peretelui toracic. Abordarea terapeutică a fost debridarea chirurgicală şi reconstrucția secundară cu lambou latissimus dorsi. Am remarcat doar o singură complicație majoră (extruzie de expander) în grupul fără radioterapie.

Concluzii: Cu toate că există o gamă largă de tehnici chirurgicale reconstructive, nu există încă un protocol clar privind reconstrucția mamară la pacientele care primesc radioterapie. Majoritatea pacientelor tind să opteze pentru cea mai simplă intervenție, si anume reconstrucția prin expanderimplant, care este de obicei însoțită de complicații atunci când este combinată cu radioterapia. Comunicarea eficientă şi deschisă între oncolog, radioterapeut, chirurg plastician şi pacient asigură rezultate optime.

Cuvinte cheie: sân, reconstrucție, autolog, aloplastic, radioterapie, complicații, întârziat

\begin{abstract}
Background and objectives: Nowadays, breast cancer treatment spans from simple lesion excision to complex management including surgery (mastectomy with or without axillary lym-phadenectomy) and adjuvant treatment (chemotherapy, radiotherapy, hormonal therapy and im-munotherapy). Lately, breast reconstruction has become part of the breast cancer approach, but, while its physical and emotional benefits are undisputed, it comes with its own set of risks and complications, especially when delayed breast reconstruction after radiotherapy is performed. This paper aims to present our experience on the effects of radiotherapy in conjunction with de-layed alloplastic breast reconstruction.

Materials and Methods: We conducted a retrospective study on 16 patients with mastec-tomy for breast cancer, for whom delayed breast reconstruction was chosen. Depending on the existence of postmastectomy radiotherapy, patients were assigned to one of two groups: group 1 consisted of eight patients that received adjuvant radiotherapy and group 2 of eight patients that did not. We collected a series of data (sociodemographic, type of reconstructive intervention, adjuvant therapies, etc.) and afterwards we analyzed the cases in which complications occurred.

Results: The number and severity of complications after breast reconstruction was higher in the adjuvant radiotherapy patient group. Seven patients had complications, three of those were major: one TRAM flap partial necrosis, one expander extrusion and one chest wall cellulitis. The therapeutic approach was surgical debridement and secondary reconstruction with latissimus dorsi flap. We noted only one major complication (expander extrusion) in the no-radiotherapy group.

Conclusions: Despite the vast array of reconstructive surgical techniques at our disposal, there is still no clear protocol regarding breast reconstruction in patients receiving radiation thera-py. The majority of patients tend to opt for the simplest intervention, i.e. expander-implant recon-struction, which is usually accompanied by complications when combined with radiotherapy. Comprehensive and open communication between oncologist, radiotherapist, plastic surgeon and patient ensures optimal results.
\end{abstract}

Key words: breast, reconstruction, autologous, alloplastic, radiotherapy, delayed 


\section{Introduction}

According to the data provided by the International Agency for Research on Cancer, the incidence of breast cancer in women, globally, in 2020 , is $47.8 \%$ (1). In contrast, the mortality rate has dropped significantly in recent years due to improved screening, diagnosis and treatment methods. Surgical intervention remains the main indication for curative treatment, complementary therapies being administered according to the particularities of each case. This results in a large number of patients requiring and opting for postmastectomy breast reconstruction (2).

Breast conserving surgery assures the same level of overall survival as mastectomy. The candidates for breast conserving surgery are patients with small and monocentric tumors, younger age, favorable localization of the tumor, patient compliance, treatment carried in specialized institutions. The local disease control is obtained with radiotherapy. The absolute contraindications for breast conserving therapy are locally widespread disease and multicentricity, diffuse microcalcifications, irradiated chest wall, mutations of BRCA 1 and 2 genes, Ist or IInd trimester of pregnancy. These represent indications for radical mastectomy (3).

Postmastectomy breast reconstruction techniques available in the armamentarium of the plastic surgeon are based on:

1. alloplastic materials (expanders, implants, absorbable or non-absorbable surgical meshes, acellular dermal matrix - ADM);

2. autologous tissues: myocutaneous latissimus dorsi flap (LD), transverse rectus abdominis myocutaneous flap (TRAM), deep inferior epigastric perforator flap (DIEP), superficial inferior epigastric perforator flap (SIEA) and superior or inferior gluteal artery perforators flap (SGAP/IGAP) and even autologous fat tissue tranfer (lipofilling);

3. combination between alloplastic and autologous techniques.

The choice of an optimal reconstructive method is not easy and must take into account several factors: timing of reconstruction, breast size and shape, tissue availability both local and distant, the effects of adjuvant / neoadjuvant treatments on tissues, surgeon's option and patient's preference (4). A very important point to be made is that breast reconstruction requires extensive surgeonpatient communication and is one of the few surgical instances when the technique must be chosen according to the patient's desires (5).

With the evolution of radiotherapy, chemotherapy, chemical castration and later the apparition of guided molecular therapy that blocks hormonal receptors, several major changes take place in the strategy of breast cancer therapy (6). Indications for radiotherapy have become more common due to improved loco-regional control of the disease and increased survival (7). But along with the benefits, the side effects in terms of appearance and quality of tissues must also be considered when it comes to developing a complete treatment and reconstruction plan for breast cancer patients. The association of postmastectomy radiotherapy represents a challenge for the plastic surgeon and there are many controversies regarding the optimal time for the reconstructive intervention. Immediate breast reconstruction could lead to impaired delivery of radiotherapy and also to an increase in number of side effects compromising the surgery. There is an ongoing debate between immediate versus delayed breast reconstruction in this group of patients, with pros and cons on the optimal time, without success in achieving a standardized international protocol (8).

The aim of this study was to explore the effects of radiotherapy on postmastectomy breast reconstruction, by identifying complications in patients operated in a single center.

\section{Materials and Methods}

We conducted a retrospective study over a 24 months period (January 2014 - December 2015), on patients admitted for breast reconstruction in the Department of Plastic Surgery and Reconstructive Microsurgery within "Elias" 
Emergency University Hospital, Bucharest, Romania. We included in this study 16 patients with mastectomy for breast cancer, for whom delayed breast reconstruction was chosen. These patients were hospitalized in the Plastic Surgery Department and operated consecutively. Depending on the presence or absence of radiotherapy, we created 2 groups: group 1 consisted of 8 patients that received radiotherapy (RT) and group 2 of 8 patients without RT. In all cases that needed $\mathrm{RT}$, this was done before the reconstructive surgical intervention. We collected sociodemographic data (age, urban/rural background, the time elapsed between mastectomy and breast reconstruction, smoker status), the type of reconstructive intervention, the existence of adjuvant therapies (chemo-/radiotherapy and hormonal therapy) and we analyzed the cases in which complications after breast reconstruction occurred.

\section{Results}

\section{Group Variables}

For our study group of 16 patients, we collected the following sociodemographic data: age (at the time of reconstructive intervention), stable residence (urban/rural environment), time elapsed from mastectomy to breast reconstruction (in months) and smoker status. The average age of these patients at the moment of breast reconstruction was 46.25 years (limits between 35 and 59 ), $75 \%$ of patients came from urban areas, with an average period between mastectomy and breast reconstruction intervention of 21.81 months, $43.75 \%$ being smokers. Significant dif-ferences between groups are observed in the source environment, all patients with postmastect-omy radiotherapy coming from urban areas, as opposed to $50 \%$ in the group of patients without radiotherapy, also $75 \%$ in the RT group were smokers and only $12.5 \%$ in the non RT group (Table 1).

\section{Adjuvant Therapy}

The patients in the study groups received
Table 1. Demographic variables in the RT group and non RT group

\begin{tabular}{lc}
\hline $\mathbf{N}=\mathbf{1 6}$ & Mean results \\
\hline Age (years) & $46.25(35-59)$ \\
\hline Urban environment (\% of patients) & $75 \%$ \\
\hline Time between mastectomy and reconstruction (months) & 21.81 \\
\hline Smoker status (\% of patients) & $43.75 \%$ \\
\hline
\end{tabular}

adjuvant therapy (chemotherapy, radiation therapy and hormone therapy) either as a single method or as combination therapy. Hormone treatment was administered in $100 \%$ of patients, followed by chemotherapy in $87.5 \%$ and radiotherapy in $50 \%$ of patients.

\section{Surgical Intervention}

Delayed breast reconstruction surgery in the selected groups of patients included both alloplastic and autologous techniques which were chosen according to the surgeon's indications, patient's wishes and surgeon's experience with surgical techniques. In the non-RT group, the re-constructions were performed exclusively with alloplastic materials: in seven patients with two stage expanderimplant and in one patient with direct implant reconstruction. In the $\mathrm{RT}$ group, the reconstructive methods were much more heterogeneous: four patients had two stage $\mathrm{ex}^{-}$ pander - implant reconstruction (in one case the lower pole was reinforced with a surgical mesh, partial absorbable, in the second stage), two patients had autologous reconstructions (one reconstruction with pedicled TRAM flap and one reconstruction with autologous fat transfer) and two patients had combined techniques (LD pedicled flap and tissue expander, followed in the second stage by replacement of the expander with a definitive implant).

\section{Complications}

In our case series, the complications developed after breast reconstruction surgery were difficulty in tissue expansion, deflation of the expander, partial flap necrosis, expander extrusion and thoracic wall cellulitis (Table 2). 
Table 2. Complications and therapeutic approach in patients with distant postmastectomy reconstruction

\begin{tabular}{llcl}
\hline & Complication & Frequency & Treatment \\
\hline Minor & Difficult expansion & 2 & Capsulotomy and capsulectomy at the time of implant insertion. \\
& Partial expander deflation & 2 & Both patients had good outcomes after the implant stage of the reconstruction. \\
\hline Major & Chest wall cellulitis & 1 & Expander extraction and salvage recon-struction with latissimus dorsi flap. \\
& Partial flap loss & 1 & Surgical debridement and dressings. \\
& Expander/implant extrusion & 2 & $\begin{array}{l}\text { One salvage reconstruction with latissimus dorsi flap after implant removal. } \\
\text { One expander removal and surgical deb-ridement, no salvage reconstruction } \\
\end{array}$ \\
& & & (the patient's option). \\
\hline
\end{tabular}

We classified the last three as major complications, namely partial flap necrosis, expander extrusion and thoracic wall cellulitis. All of the others were classified as minor complications. The type of complications, their frequency and the therapeutic attitude for each of them are presented in Table 2. We had situations in which some complications overlapped in the same patient.

In the group of patients who did not receive radiotherapy, we had 2 cases with postoperative complications, one minor and one major. The major complication occurred in a patient for whom an expander was inserted as a first step in the reconstructive process. Contrary to doctor's recommandations, she wore an external prosthesis during the inflation process of the expander, which led to necrosis of the skin flap and extrusion of the expander. The tissue expander was removed and all devitalized tissues were excised, the evolution being favorable. Unfortunately, the patient later refused any other reconstructive option.

In the group of patients with adjuvant radiotherapy, the number of complications after breast reconstruction was higher. We encountered complications in 5 cases, of which three were major ones (Fig. 1). Partial flap necrosis occurred in one patient with TRAM reconstruction that was subsequently debrided. No additional procedure was needed in this case. We had two other major complications in two patients with alloplastic reconstruction: one partial necrosis of the mastectomy skin flap with subsequent extrusion of the implant and surgical mesh (Fig. 2) and one severe progressing cellulitis of the chest wall during in the expansion stage (Fig. 3). Both cases were solved by expander removal, surgical debride- ment and the breast reconstruction was performed using combined methods: implant, mesh and latissimus dorsi flap, as a salvage procedure.

\section{Discussion}

Numerous controversies exist in the literature regarding the optimal time for breast reconstruction in patients requiring radiotherapy. There are numerous reports of an increased number of complications and failure of reconstructive interventions in this group of patients, ranging from 8.7 to $40 \%$ (8-10). Radiation therapy is important in breast surgery because it has been shown to be effective in local disease control, specific breast cancer survival and overall survival (11).

We wanted to assess in our study the number and severity of complications in reconstruc-tion patients with $\mathrm{RT}$ versus those without RT. In the RT group, both minor and

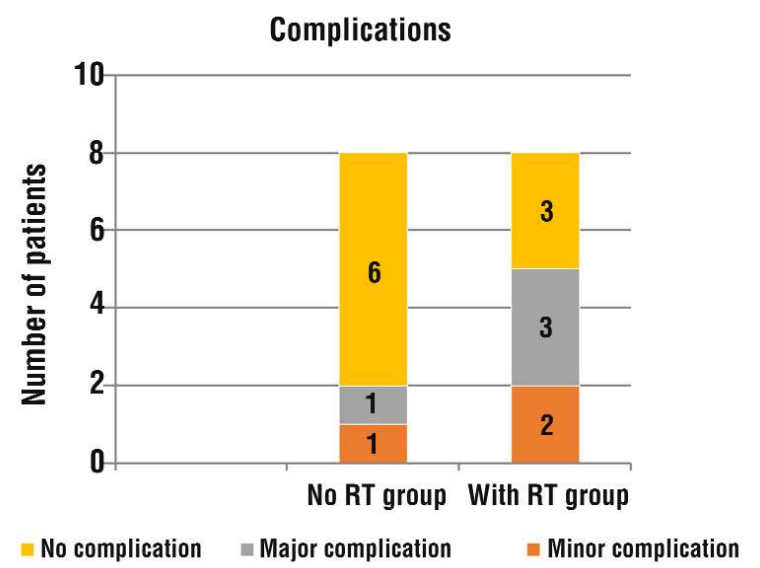

Figure 1. Number of major and minor complications that apperead in the RT and non-RT group 


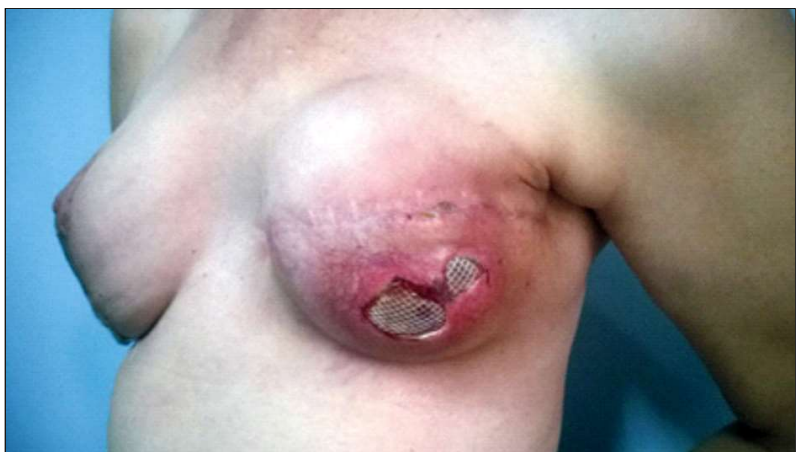

Figure 2. 47 years old patient, non-smoker, 36 months postradiotherapy, developed necrosis of the mastectomy skin flap with subsequent extrusion of the implant and surgical mesh

major complica-tions were encountered with a higher frequency and were more severe compared to the non RT group. These results are consistent with the literature, the negative effect of radiation therapy on tissues and postoperative recovery being intensively researched and substantiated (12-15).

Aesthetic results of primary treatment in breast cancer patients are as important as oncological safety. Nowadays the first choice in breast cancer is breast conservation surgery, but in some cases this is not possible due to contraindications: previously irradiated chest wall, pa-tient with mutations of BRCA $1 \& 2$ genes, locally widespread disease, multicentricity, diffuse microcalcifications, $\mathrm{I}^{\mathrm{st}}$ and $\mathrm{II}^{\text {nd }}$ trimester of pregnancy and the patient's choice (16).

Along with the undeniable benefits of hormone therapy and chemotherapy in the breast cancer management, the complications and side effects of these treatments must be considered, as they can also affect breast reconstruction surgery. In our study, all patients received hormone therapy and $87.5 \%$ of them had chemotherapy. Tamoxifen administration is an independent risk factor for thromboembolic events, breast cancer patients who receive this type of hormone treatment having a 1.5 to 7.1 fold increased risk of developing thromboembolic complications compared to breast cancer patients without hormonal therapy (17). This aspect is of particular im-portance in cases of autologous

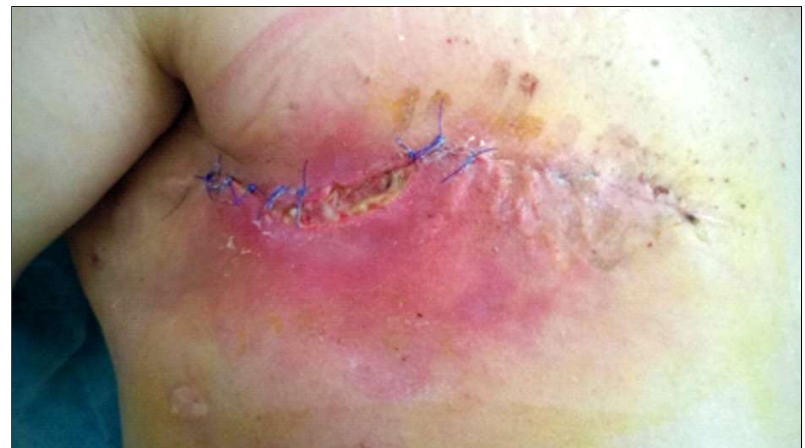

Figure 3. 42 years old patient, smoker, 7 months post-radiotherapy developed severe cellulitis of the chest wall that progressed even after the expander was removed

tissue breast reconstruction, especially microsurgical techniques. Tissue healing as well as susceptibility to infections is influenced by both chemotherapy and radi-ation therapy (11). A study performed on 344 breast cancer patients who received chemotherapy and underwent mastectomy with breast reconstruction showed that chemotherapy increases the risk of complications after breast reconstruction, no matter the time frame elapsed between chemotherapy and reconstruction (18).

The purpose of postmastectomy breast reconstruction is to restore the symmetry of the breasts and therefore to improve the patients' quality of life by building up their femininity and self-confidence. In delayed postmastectomy reconstruction, one of the major disadvantages is the need to recreate both the breast mound and the overlying skin envelope. The plastic surgeons' vast armamentarium comprises of the use of autologous tissue, alloplastic materials or a combina-tion of the two. There are many factors that must be considered before choosing the reconstructive method: on the one hand related to the characteristics and preferences of each patient, and on the other hand to the advantages and disadvantages of each technique. Although implant-based procedures are still often used, there are a large number of flaps that provide excellent aesthetic results, the most popular nowadays being the free flaps such as TRAM, DIEP, SIEA and SGAP/IGAP 
(19). Frequently we have chosen in our patients the expander-implant alloplastic reconstruction. Since the introduction of the notion of tissue expansion by Radovan in 1982, it has become a popular and widely used method in postmastectomy breast reconstruction, mainly due to a relatively easy surgical technique, but also due to the major advantage of using only local tissues (20). The cancer patients that undergo delayed breast reconstruction are usually both physically and emotionally depleted of resources and therefore the simplest option is the most appealing for them, sometimes purposefully ignoring the possibility that severe complications might occur.

The limitations of this study are given primarily by the small groups of patients who were enrolled and by unicentricity. Large multicenter studies are needed, on large groups of patients, in order to reach a consensus on the optimal timing of postmastectomy breast reconstruction in patients who also need radiation therapy.

\section{Conclusions}

Mastectomy is an indication of choice for many breast cancer patients. However, breast reconstruction is performed in few cases at the same time. Radiotherapy is becoming more common, but there is still no clear protocol regarding breast reconstruction in this particular group of patients, in which the number and severity of complications are also higher. When there are important tissue changes after radiotherapy, it is preferable to choose a combined technique from the beginning. The plastic surgeon has the duty to clearly present these limits and possible prob-lems to the patient when establishing the reconstruction plan, but he or she must also possess the ability to treat these complications, that could occur.

The reconstructive method should be chosen after a collaboration between oncologist, ra-diotherapist and plastic surgeon and according to the patient's preferences (21).
Comprehensive and open communication between the patient and the medical and surgical team ensures optimal results.

\section{Conflict of Interest}

The authors declare no conflicts of interests.

\section{Ethics Approval}

Local ethical agreement and informed consent of the patient were obtained.

\section{References}

1. Cancer today. Gco.iarc.fr. https://gco.iarc.fr/today/online-analysis-multibars?v=2020\&mode=cancer \&mode_population=countries \&population $=900 \&$ populations $=900 \&$ key $=$ asr $\&$ sex $=0 \&$ cancer $=39 \&$ type $=0 \&$ statis tic $=5 \&$ prevalence $=0 \&$ population_group=0\&ages_group $\% 5 \mathrm{~B} \% 5 \mathrm{D}=0$ \&ages _group $\% 5 \mathrm{~B} \% 5 \mathrm{D}=17 \& \mathrm{nb}$ _items=10\&group_cancer=1\&include_nmsc $=1 \& \mathrm{i}$ nclude_nmsc_other $=1 \&$ type_multiple $=\% 257 \mathrm{~B} \% 2522 \mathrm{inc} \% 2522 \% 253$ Atru e\%252C\%2522mort\%2522\%253Afalse\%252C\%2522prev\%2522\%253Af alse\%257D\&orientation=horizontal\&type_sort=0\&type_nb_items=\%257B \%2522top\%2522\%253Atrue\%252C\%2522bottom\%2522\%253Afalse \%25 7D. Published 2021. Accessed March 18, 2021.

2. U.S. Breast Cancer Statistics | Breastcancer.org. Breastcancer.org. https://www.breastcancer.org/symptoms/understand_bc/statistics. Published 2021. Accessed March 18, 2021

3. Fajdic J, Djurovic D, Gotovac N, Hrgovic Z. Criteria and procedures for breast conserving surgery. Acta Inform Med. 2013;21(1):16-19.

4. Lakhtakia R. A Brief History of Breast Cancer: Part I: Surgical domination reinvented. Sultan Qaboos Univ Med J. 2014;14(2): e166-e169.

5. Headon H, Kasem A, Almukbel R, Mokbel K. Improvement of survival with postmastectomy radiotherapy in patients with 1-3 positive axillary lymph nodes: A systematic review and meta-analysis of the current literature. Mol Clin Oncol. 2016;5(4):429-436

6. Steele KH, Macmillan RD, Ball GR, Akerlund M, McCulley SJ. Multicentre study of patient-reported and clinical outcomes following immediate and delayed Autologous Breast Reconstruction And Radiotherapy (ABRAR study). J Plast Reconstr Aesthet Surg. 2018;71(2):185-193

7. Negenborn VL, Volders JH, Krekel NMA, Haloua MH, Bouman MB, Buncamper $\mathrm{ME}$, et al. Breast-conserving therapy for breast cancer: Cosmetic results and options for delayed reconstruction. J Plast Reconstr Aesthet Surg. 2017;70(10):1336-1344.

8. Cohn SM. Chapter 78: Breats reconstruction following mastectomy. In: Surgery: Evidence-Based Practice. 1st ed. People's Medical Publishing House; 2012:1016.

9. Rancati A, Gercovich FG. Introduction to conservative mastectomies. Gland Surg. 2015;4(6):450-452.

10. Krug D. Adjuvant Radiotherapy for Breast Cancer: More than Meets the Eye. Breast Care (Basel). 2020;15(2):109-111.

11. Parikh RP, Odom EB, Yu L, Colditz GA, Myckatyn TM. Complications and thrombo-embolic events associated with tamoxifen therapy in patients with breast cancer undergoing microvascular breast reconstruction: a systematic review and meta-analysis. Breast Cancer Res Treat. 2017;163(1):1-10.

12. Payne WG, Naidu DK, Wheeler CK, Barkoe D, Mentis M, Emerick Salas R, et al. Wound healing in patients with cancer. Eplasty. 2008:8:e9.

13. Cohen O, Lam G, Choi M, Karp N, Ceradini D. Does the Timing of Chemotherapy Af-fect Post-Mastectomy Breast Reconstruction Complications? Clin Breast Cancer. 2017;17(4):307-315. 
14. Hvilsom GB, Hölmich LR, Steding-Jessen M, Frederiksen K, Henriksen TF, Lipworth L, et al. Delayed breast implant reconstruc-tion: is radiation therapy associated with capsular contracture or reoperations? Ann Plast Surg. 2012;68(3):246-52.

15. Hirsch EM, Seth AK, Dumanian GA, Kim JYS, Mustoe TA, Galiano RD, et al. Outcomes of tissue expander/implant breast reconstruction in the setting of prereconstruction radiation. Plast Reconstr Surg. 2012;129(2): 354-361.

16. Kronowitz SJ, Robb GL. Radiation therapy and breast reconstruction: a critical review of the literature. Plast Reconstr Surg. 2009; 124(2):395-408.

17. Dewael S, Vandevoort M, Fabré G, Nanhekhan L. Immediate versus delayed autologous breast reconstruction: A retrospective matched cohort study of irradiated patients. J Plast Reconstr Aesthet Surg. 2019;72(11):1769-1775.

18. Yun JH, Diaz R, Orman AG. Breast Reconstruction and Radiation Therapy. Cancer Con-trol. 2018;25(1):1073274818795489.

19. Wilkins EG, Hamill JB, Kim HM, Kim JY, Greco RJ, Qi J, et al. Complications in Postmastectomy Breast Recon-struction: One-year Outcomes of the Mastectomy Reconstruction Outcomes Consortium (MROC) Study. Ann Surg. 2018;267(1):164-170.

20. Radovan C. Breast reconstruction after mastectomy using the temporary expander. Plast Reconstr Surg. 1982;69(2):195-208.

21. Avino A, Răducu L, Brîndușe LA, Jecan CR, Lascăr I. Timing between Breast Recon-struction and Oncologic Mastectomy-One Center Experience. Medicina (Kaunas). 2020;56(2):86. 